\title{
Experimentally Determined Structural Load Paths in a 1/3-Scale Model of Light-Framed Wood, Rectangular Building
}

\author{
Peter L. Datin ${ }^{1}$, Akwasi F. Mensah ${ }^{2}$, and David O. Prevatt ${ }^{3}$ \\ ${ }^{1} \mathrm{PhD}$ Candidate, ${ }^{2}$ Graduate Student, and ${ }^{3}$ Assistant Professor, Department of Civil \& \\ Coastal Engineering, University of Florida, 365 Weil Hall, Gainesville, FL 32611; \\ email: pdatin@ufl.edu, frimensah@ufl.edu, and dprev@ce.ufl.edu
}

\begin{abstract}
It has been speculated that much of the losses from hurricane damage to single-family wood-framed residential structures is due to design based on faulty understanding of the structural load paths in these buildings. This NSF-supported research presents a new approach to understanding load paths in wood-frame residential structures and establishes a relationship between spatially varying wind loads and structural load paths. A 1/3-scale wood frame gable roof building was constructed with geometrically scaled wood members, sheathing, and nails. The model scaled the flexural stiffness $(E I)$ of the roof sheathing for wind loads applied normal to the surface. A dense grid of point loads were used to develop the influence coefficients (and surfaces) for 20 vertical reactions located at roof-to-wall and wall-to-foundation connections. The linear elastic structural response for roof-to-wall connections was limited on the roof surface to within two trusses of the applied load location. As expected there was a greater spread of load effect at the foundation level (6-8 trusses) because the exterior wood stud walls acted as stiff, vertical diaphragms. The influence functions were combined with wind tunnel pressure data for a similar shaped model from which the dynamic wind loads were estimated using a databaseassisted design methodology. There was reasonable agreement between the dynamic reaction load traces with design loads obtained by components and cladding (C\&C) design approach of ASCE7. Results also suggest the main wind force resisting system (MWFRS) method underestimates the design wind loads at roof-to-wall connections.
\end{abstract}

\section{INTRODUCTION}

Wind damage to light-framed wood structures (LFWS), and single-family residential buildings in particular, annually results in severe economic losses, mainly due to failure of joints and connections the roofs. The potential exposure is high, as nearly one-third of the United States population lives within 100 miles of a hurricane-prone (US Census Bureau 2007), and the majority of those homes (90\%) are of wood construction built before 1994, when wind-resistant building codes were first introduced. 
The National Science Board estimates that annual hurricane damage losses was about \$35.8 billion between 2001 and 2006 (NSB 2007). Sparks (Sparks 1991) concluded that the majority of the losses occur to residential LFWS, and of this most damage occurs to roof structures. While some jurisdictions have seen improvements in hurricane resistance through newer building codes (Gurley et al. 2006), residential LFWS continue to suffer structural failures that occur below design levels (van de Lindt et al. 2007).

Because the building codes for residential LWFS structures are prescriptive, there is sometimes minimal engineering basis for the design approach. Recent interest has focused on developing performance based design methodologies for LFWS that will provide more risk consistency and better reliability of LFWS (Crandell et al. 2006; Ellingwood et al. 2006; van de Lindt and Dao 2009). To further this goal, experimental studies are underway to develop better understanding of the interaction of loads with the complex structural systems in a wood-framed house to understand the system performance of the whole system.

Structural Load Paths. A structural load path is the "path" that an applied load is transferred, or "moved," through a structure from point of application to the ground. Figure 1 depicts a continuous vertical load path to resist wind uplift forces on a roof. This is one of several available pathways. Wind loads acting normal to roof sheathing is transferred through fasteners to the roof trusses, which are in turn transferred through roof-to-wall connections to the stud wall, and so on through to the foundation. The connections between structural elements must be designed to transfer the applied loads and prevent brittle failures of one component from the next.

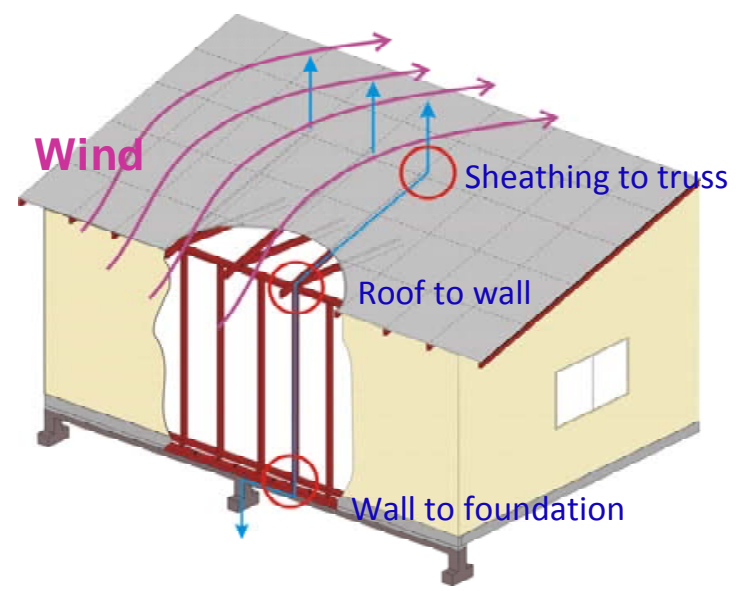

Figure 1. Vertical structural load paths (adapted from Shanmugam et al. 2008)

There is limited knowledge available regarding the actual load paths within a complex three-dimensional (3D) wood framing system that model the multiple load paths and the specific non linear connection details (metal plate trusses, nail in withdrawal, etc.) within the system. It is hypothesized that our limited knowledge of these load paths may contribute to premature failures of roof systems in high wind events below design wind speeds. Understanding the structural load paths and load transfer mechanisms in LFWS systems is critical to improving the prediction of 
structural failures in extreme wind events. It is also fundamental to developing performance-based wind design of these structures, and thereby reducing future damage and economic losses to the inventory of LFWS.

\section{OBJECTIVE}

The goal of this research is to determine the structural load paths in a residential LFWS for wind uplift loads. Understanding how uplift loads generated by extreme winds are transferred through the structure will provide greater understanding and insight into how and why roof failures are still common in hurricanes.

\section{SCALE HOUSE DEVELOPMENT}

A one-third scale structural model of a LFWS building was constructed using geometric scaling laws (Harris and Sabnis 1999) and wood materials. The prototype house measured $9.1 \mathrm{~m}(30 \mathrm{ft})$ wide by $12.2 \mathrm{~m}$ (40 ft) long with $2.5 \mathrm{~m}(8 \mathrm{ft})$ tall walls. The house had a 4 in 12 pitch gable roof with $0.45 \mathrm{~m}$ (18 in.) long overhangs around its perimeter. The structural framing material was southern yellow pine (SYP) for roof trusses and spruce pine fir (SPF) for the exterior walls (typical of light-frame construction in the Southeastern United States) scaled to 1/3 of full scale. Roof trusses were fabricated after Gupta et al. (2005) with member dimensions $12.7 \mathrm{~mm}$ (0.5 in.) by $29.7 \mathrm{~mm}$ (1.17 in.) in cross-section. In order to simplify the similitude requirements between the full-scale and model-scale trusses, the modulus of elasticity (MOE) of the model framing members needs to be equal (or nearly equal) to that of the full-scale boards. The MOE of the framing members was determined according to ASTM 4761 (ASTM 2004b). For the sheathing, the flexural stiffness (EI) needs to be properly modeled to accurately represent load transfer in full-scale ( $E=$ modulus of elasticity and $I=$ moment of inertia).

Since wind loads produce out-of-plane loading on the roof (and subsequently the sheathing), the sheathing needs to perform appropriately in the out-of-plane direction. For this reason, the flexural stiffness was determined to be the property of interest. The flexural stiffness is scaled by $(E I)_{p}=S_{E} S_{L}^{4}(E I)_{m}$ and if $E$ is constant then this yields (for a $1 / 3$ geometric scale): $(E I)_{p}=(1)\left(3^{4}\right)(E I)_{m}=81(E I)_{m}$. Therefore, the target model stiffness was chosen as 1/81 times the full-scale flexural stiffness of 12.7 mm (0.5 in.) thick sheathing, experimentally determined per ASTM 3043 (ASTM 2004a).

In selecting the sheathing attachment, several factors were considered. Since the ultimate objective of the one-third scale house is determining the structural load paths for wind uplift loads and since the model house cannot be taken to failure with any meaningful results, it was decided to ensure that the connections between the sheathing and framing members did not fail, especially due to the point loads applied directly to the sheathing. Figure 2 shows the fasteners that were tested in withdrawal according to ASTM D1761 (ASTM 2006). Because of the failure mode for the nails (nail withdrawal from the framing member and nail pulling through the sheathing), 
the \#4 wood screw was selected and then used at four inches on center for attaching the sheathing to the walls and the roof.

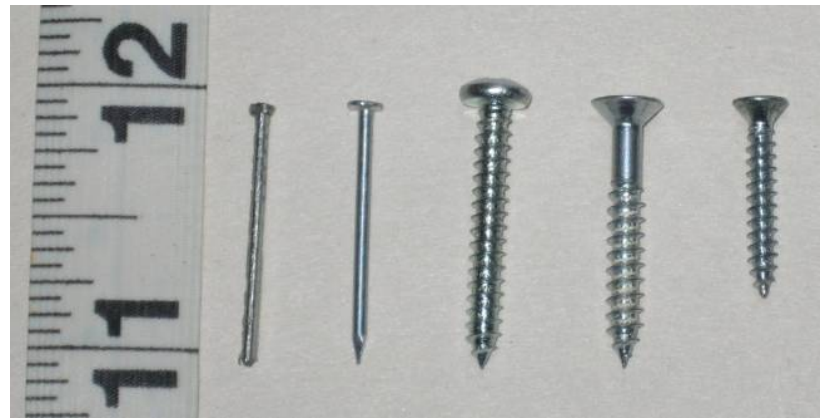

Figure 2. Sheathing fasteners tested

\section{METHODS AND MATERIALS}

Load cells were installed at eleven roof-to-wall connection locations, shown in Figure 3a and Figure 3b, including three load cells placed along the span of the one gable end truss attaching the bottom chord to the top of the wall directly below. Spacer supports were installed at the remaining 34 roof-to-wall connections (Figure 3c). Nine load cells were placed at wall-to-foundation connections, as shown in Figure 4. The locations of the twenty load cells is shown in Figure 5a. The house was then sheathed with the 0.25 in. thick OSB determined previously with 0.75 in. long \#4 screws spaced at four inches on center. The completed one-third scale house is shown in Figure 5b. The overhangs were also sheathed on the underside.
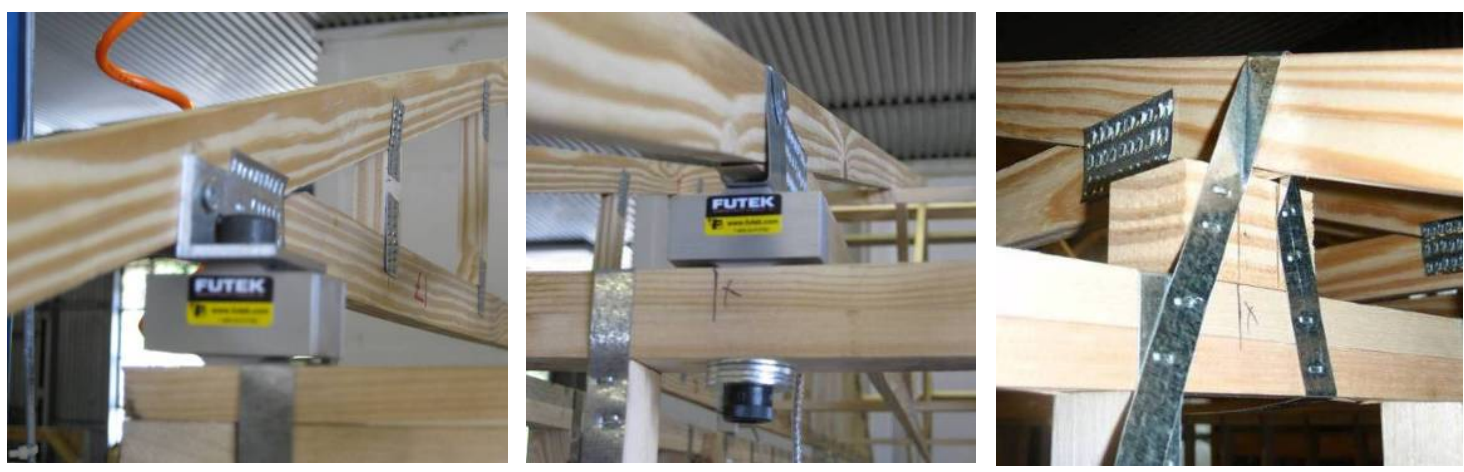

Figure 3. Roof-to-wall connections: (a) gable end truss with load cell; (b) interior truss with load cell; and (c) interior truss without load cell

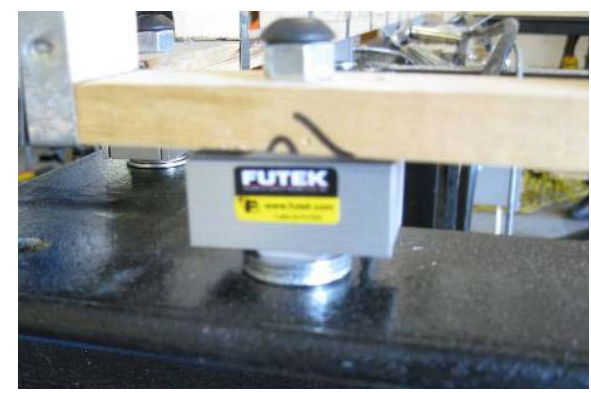

Figure 4. Wall-to-foundation connection with load cell 

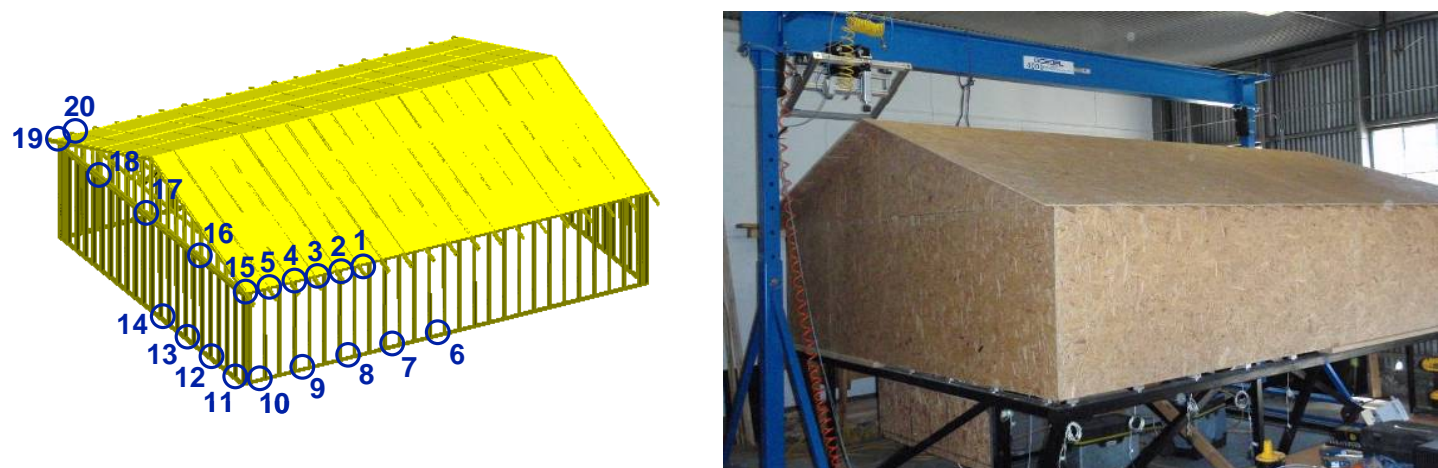

Figure 5. (a) Placement of load cells in scale house and (b) Completed 1/3-scale wood-framed house

\section{INFLUENCE FUNCTIONS}

Point loads were applied in a grid pattern (see Figure 6b) normal to the roof surface using a pneumatic actuator (see Figure $6 \mathrm{~b}$ ) to determine vertical reaction influence functions for several roof-to-wall and wall-to-foundation connections (see Figure 5a). The actuator was controlled with a LabVIEW software program that used a load cell mounted on the end of the actuator as a feedback loop to maintain the desired load. This LabVIEW software program also logged the results of each instrumented reaction point. The applied loads varied from $44.5 \mathrm{~N}$ (10 lbs) to $222 \mathrm{~N}$ (50 lbs) in steps of $44.5 \mathrm{~N}$ (10 lbs) corresponding to full-scale point loads ranging from $400 \mathrm{~N}$ (90 lbs) to $2 \mathrm{kN}$ (450 lbs). The loads were applied as both uplift and gravity (downward) loads. A static equilibrium check confirmed that load cells accurately recorded the total applied loads.
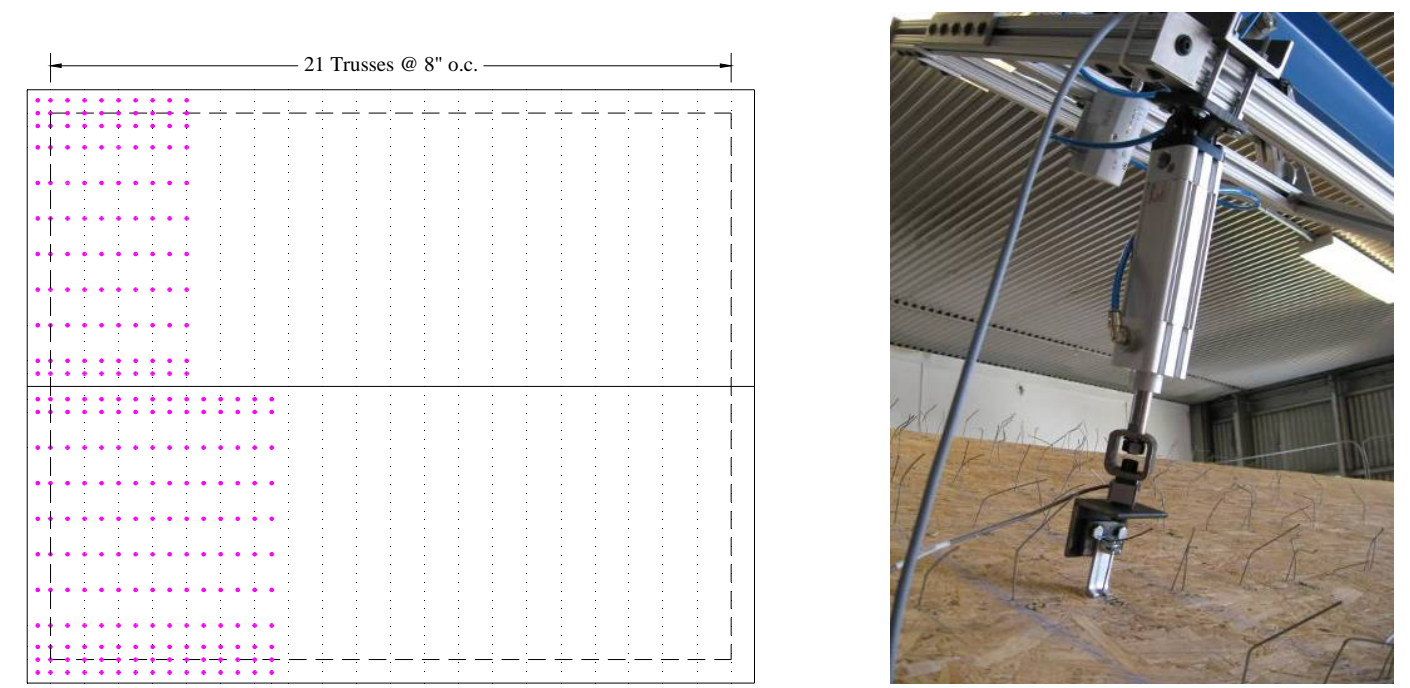

Figure 6. (a) Roof loading points and (b) Pneumatic actuator used for load application 
Results: Contour plots of two roof-to-wall connections are shown in Figure 7 and for two wall-to-foundation loads in Figure 8. The influence function plot in Figure 7 for the interior truss is typical for the reaction points of interior trusses. The highest influence coefficients are centered above or near to the reaction point and the for interior roof-to-wall connections, the influence functions extend only as far as one truss on either side ( $4 \mathrm{ft}$ total at full scale) of the reaction point. Figure 7 shows that for the gable end truss reactions, the influence functions are largest when the applied load is over the eaves and taper off rather quickly moving away from the corner of the roof.

Figure 8 shows the influence surface for the wall-to-foundation connection indicating a much lower influence coefficient of only 0 to $20 \%$ of the applied point load. This occurs because the vertical wall acts as a stiff, deep beam spreading the loads well beyond the localized region of load. The reaction of the corner wall-to-foundation (Figure 8) attracts a slightly higher proportion of the applied vertical load (>20\%).

An interesting comparison of the load distribution in the gable end truss was done by removing the three load cells between the top of the wall and bottom chord of gable truss (LC \#16, \# 17, and \#18). The comparison in Figure 9 shows an increase in area of influence when the intermediate load cells were removed.
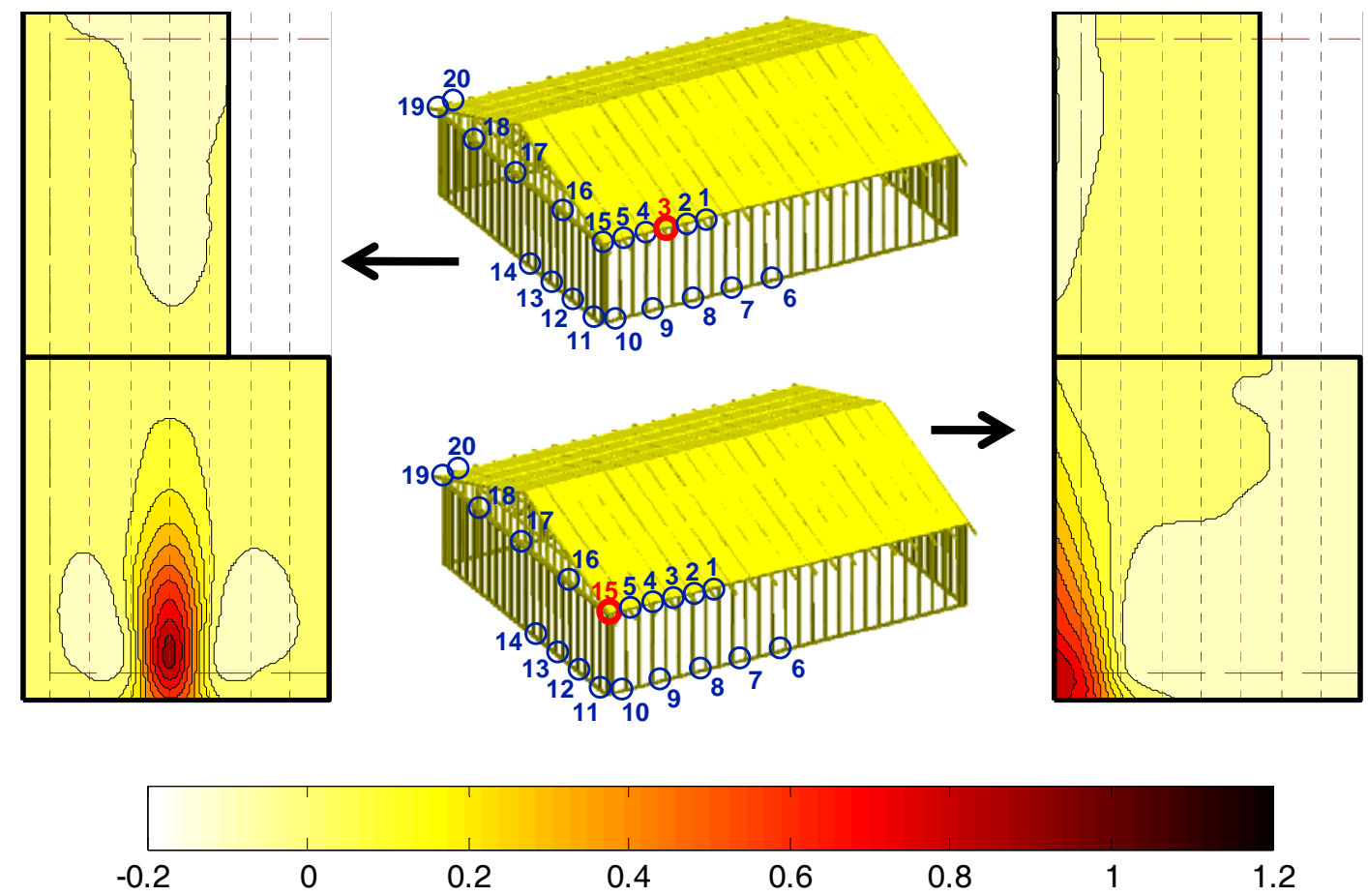

Figure 7. Influence functions for typical roof-to-wall connections - interior truss (left) and gable end truss (right) 

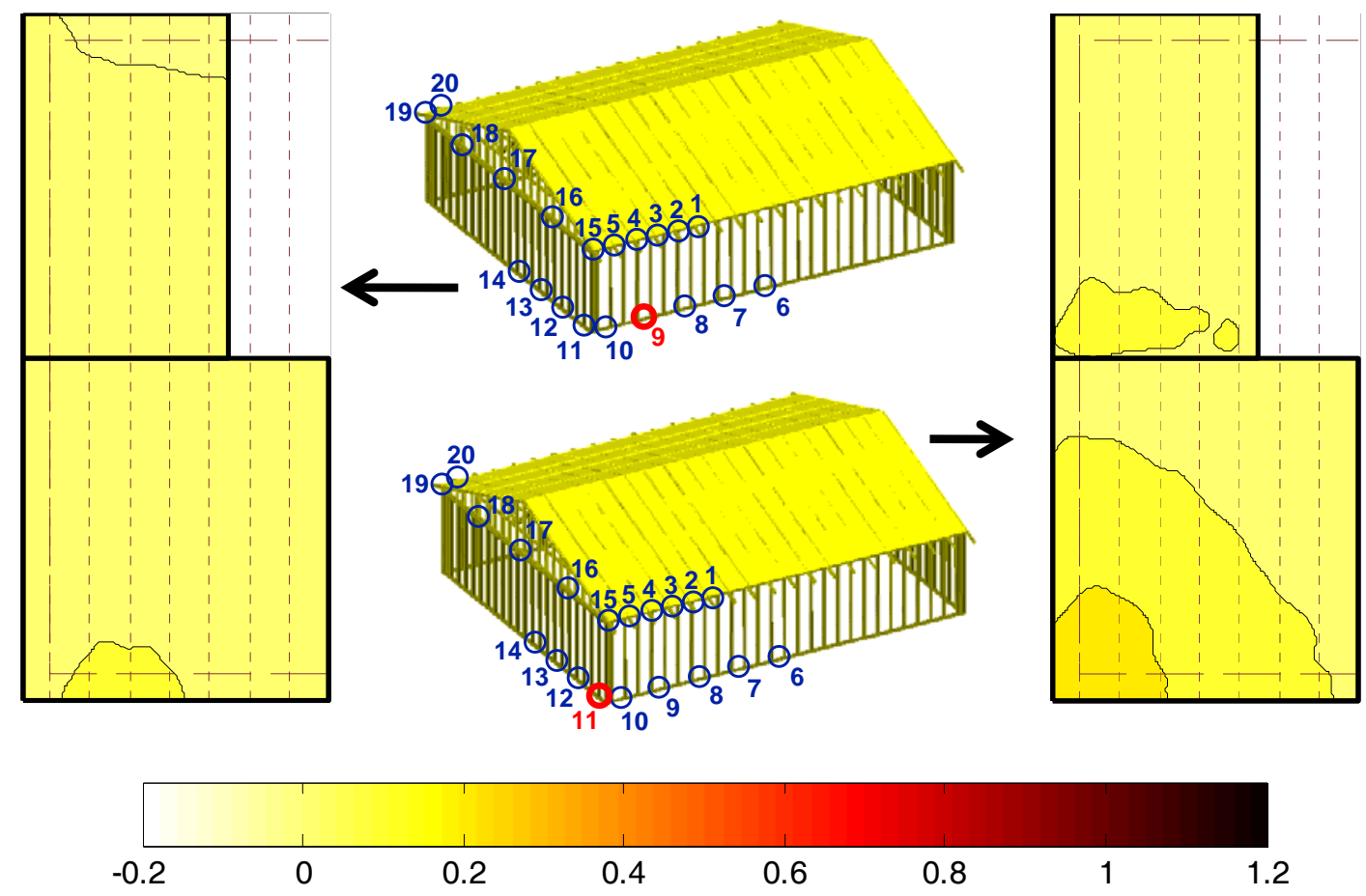

Figure 8. Influence functions for typical wall-to-foundation connections interior connection (left) and corner connection (right)
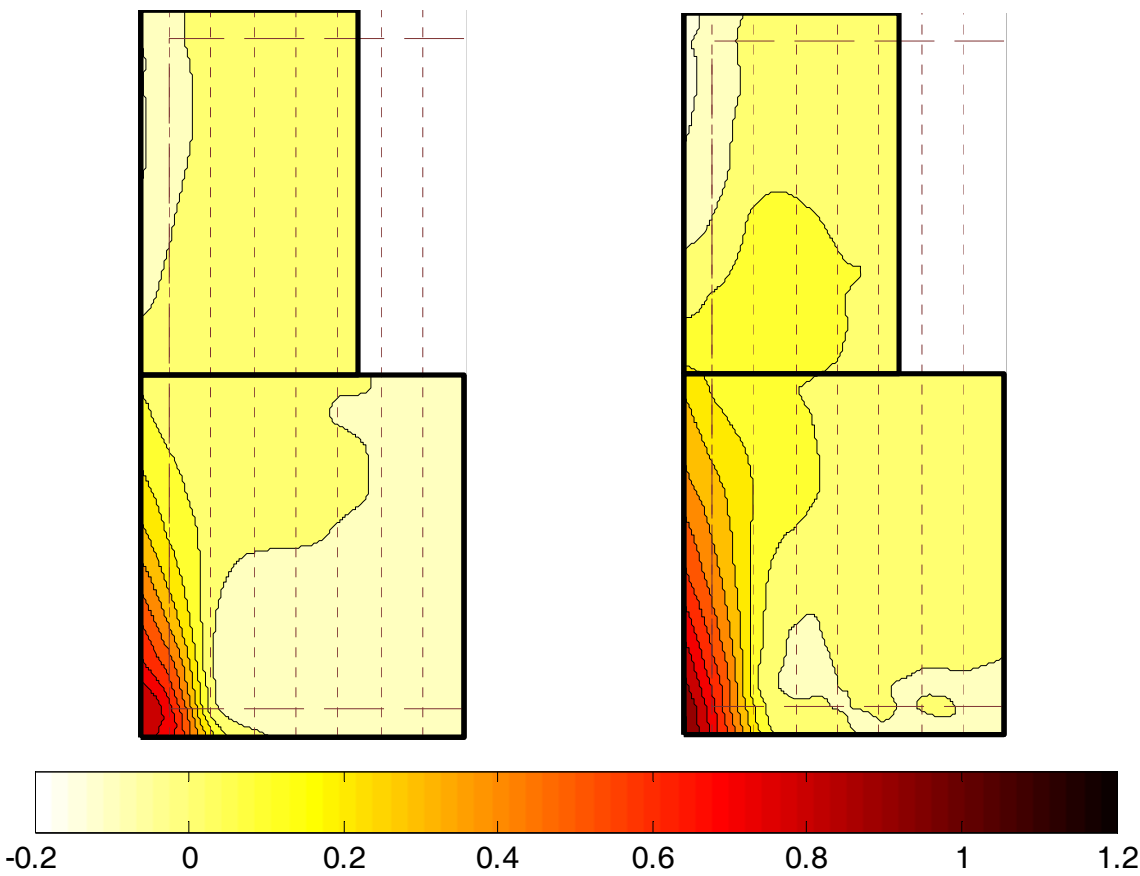

Figure 9. Influence functions for gable end truss reaction with load cells along gable end (left) and without load cells along gable end (right) 


\section{PREDICTING REACTION LOADS}

The database-assisted design (DAD) methodology has been proposed for the wind uplift design of low-rise buildings in a risk consistent manner. The DAD method (Main and Fritz 2006; Whalen et al. 1998; 2002) uses wind tunnel pressure time histories, along with structural influence functions to predict the peak design loads within a structure. For this study, aerodynamic pressure data on the house for five wind directions $\left(0^{\circ}, 45^{\circ}, 90^{\circ}, 135^{\circ}\right.$, and $\left.180^{\circ}\right)$ were developed using a $1: 50$ scale model reported in Datin and Prevatt (2007). Overall pressure distributions were determined using a high-frequency Scanivalve system and near-simultaneous pressure measurements on 386 roof pressure taps. These peak roof wind pressure results were calculated as:

$$
P(t)=0.5 \rho C_{p}(t) V_{m r h, s u b}^{2} \quad \text { where } \quad V_{m r h, s u b}=\left(K_{z}\right)^{1 / 2} V_{o p e n, 10 m}
$$

where $C_{p}(t)$ is the pressure coefficient at time $t$, as determined from the wind tunnel tests; $V_{m r h, s u b}$ is the 3-second gust wind speed at the mean roof height for suburban terrain, $\rho$ is the density of air; $K_{z}$ is the velocity pressure exposure coefficient provided in Table 6-3 of ASCE 7-05 (ASCE 2006); and $V_{\text {open,10m }}$ is the basic design wind speed given in Figure 6-1 of ASCE 7-05.

Vertical reaction time histories were determined using a database-assisted design (DAD) methodology to combine the pressure distributions with influence functions for the reactions. The instantaneous reactions were determined as:

$$
R_{j}(t)=\sum_{i=1}\left(P_{i}(t) N_{j i} A_{i}\right)
$$

where $j$ is the connection number; $i$ is the location of influence function points; $N_{j i}$ is the influence function for the $j^{\text {th }}$ connection; and $A_{i}$ is the tributary area of $i^{\text {th }}$ influence function point. Summary statistics for a wind direction of $0^{\circ}$ are shown in Figure 10.

Results are presented for both roof-to-wall and wall-to-foundation reactions as well as with the intermediate load cells (numbers 16-18) included and then removed. As can be seen, the reaction loads for the gable end truss (connections 15 and 19) change drastically when the intermediate load cells are removed. Figure 11 compares the peak vertical reactions at selected roof-to-wall connections determined using the DAD approach in comparison to values obtained using ASCE 7-05 (ASCE 2006) provisions using (a) Main Wind-Force Resisting System (MWFRS) and (b) Components and Cladding (C\&C) provisions. As can be seen, the MWFRS loads tend to underestimate the reaction loads, especially the gable end reactions (connections 15 and 19). However, the C\&C loading tends to be a more reasonable prediction of the maximum loads. The significance of this finding is that according to ASCE 7-05 (ASCE 2006), the trusses are part of the MWFRS and therefore their reactions would be designed according to MWFRS. However, as Figure 11 shows, this may be non-conservative and inappropriate. 

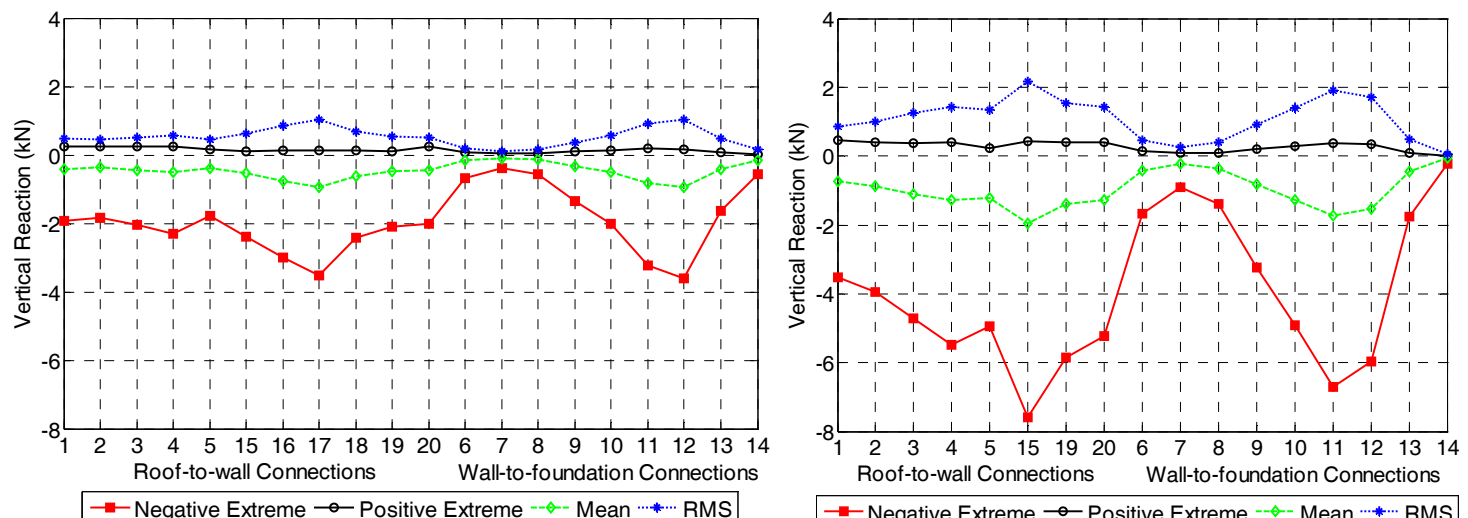

Figure 10. Summary statistics for predicted reaction time histories with the gable end load cells installed (left) and without the gable end load cells (right)
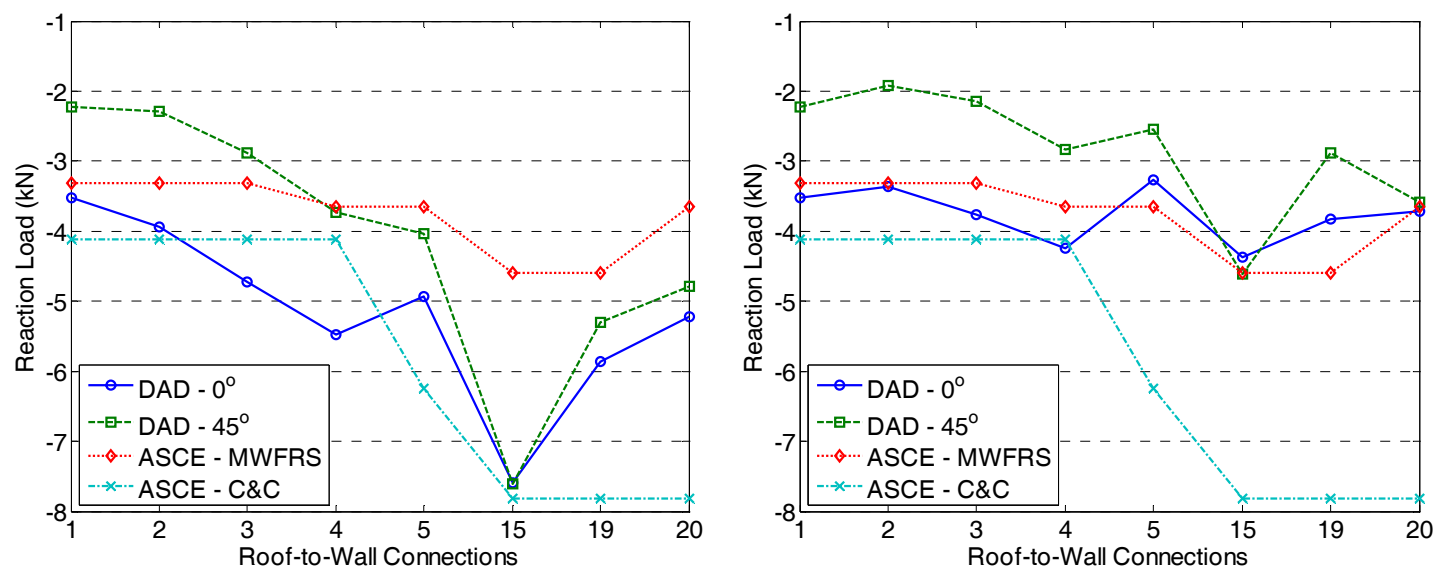

Figure 11. Predicted vertical reaction loads at roof trusses using DAD methodology and ASCE 7-05 without gable end load cells (left) and with gable end load cells (right)

\section{CONCLUSION}

A 1/3-scale wood-frame residential building was constructed for the purpose of determining vertical influence functions at critical connections in the structure namely the roof-to-wall and wall-to-foundation connections. As the structure stays within the linear elastic range, the magnitude of the applied load has virtually no effect on the measured influence functions. For interior trusses, the area of influence is primarily within one to two trusses on either side of the truss of influence. In other words, loads applied more than two trusses away do not appear to have much effect on that truss reaction. For gable end trusses, the area of influence decreases if the truss is anchored intermediately to the wall directly below it. For wall-to-foundation connections, the load is spread more evenly among the connections (i.e. not as concentrated directly below an applied load) likely due to the sheathed wall acting as a deep, stiff beam effectively distributing the load to reactions farther from the point 
of load application. The database-assisted design analysis showed that using MWFRS loads to design truss reactions may be non-conservative and inappropriate, especially for gable end trusses. The C\&C design loads provide a more reliable method to design the truss reactions.

\section{ACKNOWLEDGEMENTS}

The authors are appreciative of the financial support through the Hazard Mitigation and Structural Engineering (HMSE) Program at the National Science Foundation (NSF) through grant \#080023, "Performance Based Wind Engineering (PBWE): Interaction of Hurricanes with Residential Structures.” The first author is also grateful to the financial support provided by the Alumni Fellowship at the University of Florida.

\section{REFERENCES}

ASCE. (2006). Minimum Design Loads for Buildings and Other Structures (ASCE/SEI Standard 7-05), American Society of Civil Engineers, Reston, VA.

ASTM. (2004a). "D 3043-00 Standard Test Methods for Structural Panels in Flexure." Annual Book of ASTM Standards, American Society for Testing and Materials, 427-439.

ASTM. (2004b). "D 4761-02a Standard Test Methods for Mechanical Properties of Lumber and Wood-Base Structural Material." Annual Book of ASTM Standards, American Society for Testing and Materials, 535-544.

ASTM. (2006). "D 1761-06 Standard Test Methods for Mechanical Fasteners in Wood." Annual Book of ASTM Standards, American Society for Testing and Materials, 267-277.

Crandell, J. H., Kenney, T. M., and Rosowsky, D. V. (2006). "Residential Building Loads - Review and Roadmap for Future Progress." American Society of Civil Engineers, Reston, VA.

Datin, P. L., and Prevatt, D. O. (2007). "Wind Uplift Reactions at Roof-to-Wall Connections of Wood-Framed Gable Roof Assembly." 12th International Conference on Wind Engineering, Australasian Wind Engineering Society, Cairns, Australia.

Ellingwood, B. R., van de Lindt, J. W., Gromala, D. S., Rosowsky, D. V., Gupta, R., and Pryor, S. E. (2006). "Performance-Based Engineering for Light-Frame Wood Construction in the United States: Status and Challenges." Proc. of the 2006 World Conference on Timber Engineering, Portland, OR.

Gupta, R., Miller, T. H., and Kittel, M. R. (2005). "Small-scale modeling of metalplate-connected wood truss joints." Journal of Testing and Evaluation, 33(3), 139-149.

Gurley, K., Davis Jr, R. H., Ferrera, S.-P., Burton, J., Masters, F., Reinhold, T., and Abdullah, M. (2006). "Post 2004 Hurricane field survey - An evaluation of the relative performance of the standard building code and the Florida building code." ASCE Structures Congress 2006, American Society of Civil Engineers, Reston, VA 20191-4400, United States, St. Louis, MO, United States, 8. 
Harris, H. G., and Sabnis, G. M. (1999). Structural Modeling and Experimental Techniques, CRC Press, Boca Raton, FL.

Main, J. A., and Fritz, W. P. (2006). "Database-Assisted Design for Wind: Concepts, Software, and Examples for Rigid and Flexible Buildings." National Institute of Science and Technology, Gaithersburg, MD.

NSB. (2007). "Hurricane Warning: The Critical Need for a National Hurricane Research Initiative." National Science Board of the National Science Foundation, Arlington, VA.

Shanmugam, B., Nielson, B. G., and Prevatt, D. O. (2008). "Probabilistic descriptions of in-situ roof to top plate connections in light frame wood structures." Proceedings of the 2008 Structures Congress - Structures Congress 2008: Crossing the Borders, American Society of Civil Engineers, Vancouver, BC, Canada.

Sparks, P. R. (1991). "Hurricane Hugo in perspective." NIST Special Publication 820, National Institute of Standards \& Technology, 29-37.

US Census Bureau. (2007). "2007 Population Estimates." US Dept. of Commerce, Economics and Statistics Administration, Washington, D.C., Accessed 9/16/2009 from factfinder.census.gov.

van de Lindt, J. W., and Dao, T. N. (2009). "Performance-Based Wind Engineering for Wood-Frame Buildings." Journal of Structural Engineering, 135(2), 169177.

van de Lindt, J. W., Graettinger, A., Gupta, R., Skaggs, T., Pryor, S., and Fridley, K. (2007). "Performance of Woodframe Structures During Hurricane Katrina." Journal of Performance of Constructed Facilities, 21(2), 108-116.

Whalen, T., Simiu, E., Harris, G., Lin, J., and Surry, D. (1998). "The use of aerodynamic databases for the effective estimation of wind effects in main wind-force resisting systems: application to low buildings." Journal of Wind Engineering and Industrial Aerodynamics, 77-78, 685-693.

Whalen, T. M., Sadek, F., and Simiu, E. (2002). "Database-assisted design for wind: Basic concepts and software development." Journal of Wind Engineering and Industrial Aerodynamics, 90(11), 1349-1368. 